\title{
Establishment of 1600 hectares in dryland species around Oamaru/Timaru
}

\author{
GAVIN MILNE and TOM FRASER \\ DSIR Grasslands, Private Bag, Palmerston North and Christchurch
}

\begin{abstract}
The Drought Pasture Demonstration Programme invloves 81 farms in the North Otago and South Canterbury areas, with an average 19.7 ha per farm, and total area of 1595 ha. The purpose is to demonstrate, in a practical and effective...way, the benefits and establishment methods of drought tolerant pasture species. Ten different species of forage grasses, legumes and herbs were used, comprising 19 different cultivars. Half the area was sown in February and March 1989 with the remaining areas sown in spring 1989 and autumn 1990. Sowing was done by either full cultivation, minimum tillage or direct drilling. A 97\% success rate was achieved in establishing these pastures, despite a dry and mild autumn, demonstrating to farmers that with correct technical advice the risks of poor establishment are low. The aspects most important for pasture establishment were paddock - preparation, moisture at sowing, timing, sowing depth, insect control, soil fertility, initial grazing, and patience. A survey of farmers has shown that a large number of farmers in the region have already viewed the demonstration pastures, and subsequently sown their own.
\end{abstract}

Keywords dryland, pasture establishment, drought, technology transfer

\section{Background}

In November 1988, Parliament approved a programme to renew 1500 ha of drought-affected pasture in the North Otago and South Canterbury area.

The purpose was to demonstrate the benefits of the drought-tolerant species. These species have been available for many years, but have still not commonly been used by farmers in the dryland regions. A 1985 farmer survey showed that $76 \%$ of farmers thought that district paddock-size demonstration areas would be the best way of promoting new pastures (Belgrave et al. 1990), and this information was used to develop a new approach to technology transfer.

The approach accepts that most effective technology adoption occurs "over the back fence", and aims to give as many farmers as possible practical, and working examples of the technology on farms similar to their own. This should give them the knowledge and confidence to use the new technology themselves.

A total of 81 farms were chosen from 316 applications.

The total area involved in the programme was 1595 ha, an average of 19.7 ha per farm.

The first phase of the programme, pasture establishment, was completed in March 1990. The second phase, promotion of results, will occur in the summers of 1991 and 1992.

Field days will be held on some of the sites once pastures have established and meaningful measurements have been taken.

\section{The 1988-89 drought}

The North Otago and South Canterbury regions had a severe drought which began in March 1988 and ended in May 1989. Allthough the spring o f 1989 was relatively moist, the period from January to May 1990 was also very dry. 1988 was the second driest year since 1913 (the driest was 1985).

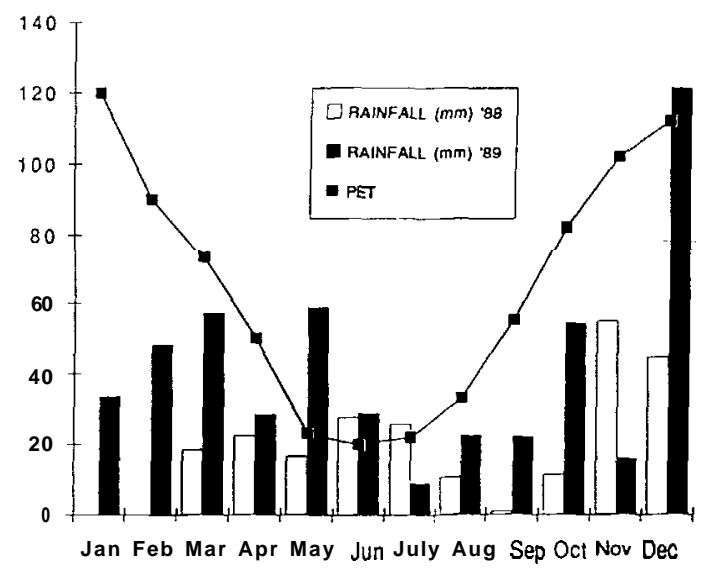

Figure 1 Rainfall and PET (mm) at Duntroon, North Otago. 
Table 1 Pasture growth at Windsor, North Otago.

\begin{tabular}{lrccr}
\hline & \multicolumn{3}{c}{ Pasture growth } & \multicolumn{2}{c}{ (kg DM/ha) } \\
& Grass & Clover & Weeds & Total \\
\hline Winter 88 & 0 & 0 & 0 & 0 \\
Spring & 0 & 0 & 0 & 0 \\
Summer & 764 & 0 & 245 & 1009 \\
Autumn 89 & 918 & 11 & 135 & 1064 \\
TOTALS & 1682 & 11 & $\mathbf{3 8 0}$ & $\mathbf{2 0 7 3}$ \\
Grass composition: & $70 \%$ & Ryegrass & & \\
& $30 \%$ Cocksfoot & \\
\hline
\end{tabular}

For the 12 months from March 1988 to February 1989 , only $314 \mathrm{~mm}$ of rain fell at Duntroon in the Waitaki valley (Figure 1), which was $57 \%$ of the average annual rainfall of $549 \mathrm{~mm}$. Over the same period, potential evapotranspiration (PET) totalled $782 \mathrm{~mm}$ and soils were at wilting point for most of that time. Rainfall exceeded PET for only 5 of the 27 months recorded.

As a result of the drought, there was no measurable pasture growth from May 1988 to January 1989 (Table 1). Some growth in summer and autumn of 1989 gave a total yield of $2073 \mathrm{~kg} \mathrm{DM} / \mathrm{ha}$ for the 12 months from June 1988 (ryegrasscocksfoot sward), only $31 \%$ of the annual average. On average, farms had destocked $50 \%$ by November and were still down 31\% in July 1989 (Anon 1989).

The decline in pasture production was magnified by widespread and severe grass grub damage, through autumn, winter and spring of 1989. The damage had been overlooked by some observers, and was also a major cause of pasture death during this period.

\section{Methods}

\section{Site selection}

Sites were selected from the 316 applications by two committees consisting of local members of Federal Farmers, MAF, Catchment Boards, and farmer resource committees. Their brief was to select sites they thought were best able to demonstrate the benefits of new pasture species. The criteria for selection included geographic and farm type spread, and farmer experience of drought species.

\section{Technical assistance (for phase 1)}

Farms south of Waimate were serviced by Gavin Milne, and those to the north by Tom Fraser; both are specialist pasture advisers with DSIR Grasslands.

Farmers received a preliminary visit in January 1989, followed by a visit in February 1989 to select pasture seed mixes and discuss management requirements. Pasture mixes and establishment techniques were designed to suit each farm and paddock, with most farms needing different seed mixtures for each paddock to accommodate the variation in soil type, aspect and farm management needs.

Visits were also made in May and August 1989 and May 1990 to evaluate sown pastures, discuss ongoing management with the farmer and review sowing plans for pastures not yet sown.

\section{Species and cultivars}

Ten different species of grass, legumes and herbs were used. Of these species, there were 19 cultivars (Table 2). Separate mixtures were designed for each paddock.

Table 2 Species and cultivars used, adjusted for seed size.

\begin{tabular}{|c|c|c|c|c|}
\hline \multirow[b]{2}{*}{ Cultivar/species } & \multirow[b]{2}{*}{ Total $\mathrm{kg}$} & \multicolumn{3}{|c|}{ Percentages } \\
\hline & & by & Weight & Adjusted \\
\hline 'Grasslands Roa' tall fescue & 15418 & & 44.6 & 21.6 \\
\hline 'AU Triumph' tall fescue & 1745 & & 5.1 & 2. 4 \\
\hline 'S170' tall fescue & 40 & & 0.1 & 0.1 \\
\hline 'Grasslands Wana' cocksfoot & 4493 & & 13. 0 & 10.5 \\
\hline 'Saborto' cocksfoot & 258 & & 0.7 & 0.6 \\
\hline 'Grasslands Maru' phalaris & 1345 & & 3.9 & 3.8 \\
\hline 'Grasslands Huia' white clover & 1786 & & 5.2 & 16.7 \\
\hline 'Grasslands Tahora' white clover & 1813 & & 5.2 & 16.9 \\
\hline 'Woogenellup' sub. clover & 1342 & & 3.9 & 7.5 \\
\hline 'Grasslands Pawera' red clover & 1688 & & 4.9 & 9.5 \\
\hline 'Grasslands Oranga' lucerne & 764 & & 2.2 & 2.1 \\
\hline 'Grasslands Otaio' lucerne & 926 & & 2.7 & 2.6 \\
\hline Yarrow & 17 & & 0.0 & 0.5 \\
\hline 'Grasslands Matua' prairie grass & 1990 & & 5.8 & 2.2 \\
\hline 'Grasslands Hakari' brome & 648 & & 1.9 & 0.7 \\
\hline Lotus corniculatus & 25 & & 0.1 & 0.2 \\
\hline 'Grasslands Puna' Chicory & 154 & & 0.4 & 1.4 \\
\hline Wheatgrass & 56 & & 0.2 & 0.3 \\
\hline Sheep's burnet & 40 & & 0.1 & 0.3 \\
\hline TOTAL & 34548 & & & \\
\hline
\end{tabular}


All grasses and herbs used tolerate drought, and are either tolerant of or resistant to grass grub and Argentine stem weevil. Of the legumes used, only white clover is susceptible to drought, although it does seem to recover from buried stolons and seed. White clover was included for its nitrogen fixation and high feed value. Where subterranean clover did not already exist in the paddock, it was included in the seed mixture.

\section{Sowing}

Pastures were established by either full cultivation, minimum cultivation or direct drilling. The decision on which method to use was based on the erosion risk of each paddock. Several of the paddocks were also fallowed before the programme began.

Most farmers used their own drills, and a few used contractors for direct drilling.

\section{Timing}

All autumn sowings had to be completed by 30 March to allow slow species to establish before the expected hard winter frosts. Sowing did not commence until soil moisture levels were good.

Half the sowings had to be delayed until spring 1989 and autumn 1990 as soil moisture was not adequate before 20 March 1989. These sowings were mainly the paddocks that were to be direct drilled or minimum tilled; most of the cultivated and fallowed ground was sown in autumn 1889.

\section{Fertiliser}

Soil samples were taken from all sites, and fertiliser rates were determined from the results. Nitrogenbased fertiliser (N:P:K:S, 20:10:0:13) was applied on most sites $(100-150 \mathrm{~kg} / \mathrm{ha})$, with the balance as superphosphate $(\mathbf{1 0 0 - 2 0 0} \mathrm{kg} / \mathrm{ha})$.

\section{Results}

\section{General}

In 1989 rainfall remained very low until 25 February in South Canterbury, and until 12 March in North Otago (Figure 1). 1989 sowings in South Canterbury took place between 25 February and 30 March, and between 15 and 30 March in North Otago.

During the month after sowing in 1989 (April), only $22.4 \mathrm{~mm}$ of rain fell in North Otago, when PET values averaged $50 \mathrm{~mm}$ (Figure 1). This placed some of the new pastures under stress. Paddocks sown after the $\overline{r a i n}$ on 20 March had āñ incomplete establishment, with the balance of seed establishing in May. Those paddocks sown earlier suffered more from moisture stress, as they had established before the moisture stress occurred and were at a more vulnerable stage.

Weeds were very thick in some paddocks, because of moisture stress limiting growth of sown plants and the mild autumn which favoured weed growth. The problem winter weeds were chickweed (Stellaria media), speedwell (Verconica arvensis), nodding thistle (Carduus nutans), and stinging nettle (Urtica

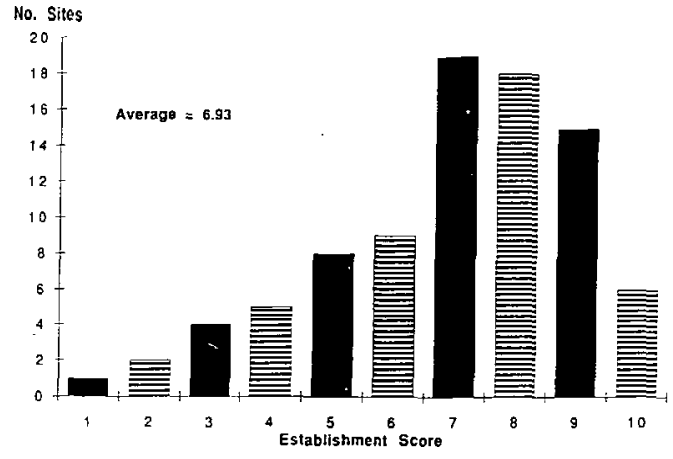

Figure 2 Establishment Score, (1-10), North Otago sites. (I $=$ poor; $10=$ very good)

urens), and fathen (Chenopodium album) in the spring sowings. A few paddocks were sprayed for weeds between May and July.

Pastures sown in spring 1989 received reasonable moisture until December, and between December and May 1990 only $130 \mathrm{~mm}$ of rain fell, while PET totalled $330 \mathrm{~mm}$. This lack of moisture, and fathen (Chenopodium album) competition, reduced plant numbers and tiller development.

Autumn 1990 was extremely difficult for pasture establishment, as only $130 \mathrm{~mm}$ of rain fell from January to the end of April, but the fallowing of paddocks meant almost no failures have occurred to date.

Despite the unfavourable conditions in both 1989 and 1990 , only $3 \%$ of the pastures have had to be resown, and only 7\% of North Otago-Waimate sites had an establishment rating less than 3 out of 10 , as assessed by the pasture specialists (Figure 2). Most failüres were dùe to deep drilling, lāck of insecticidè (on organic farms), or insect damage despite insecticide use.

Some paddocks established extremely well. A paddock of 'Grasslands Matua' prairie grass was grazed three times before June 1989 from a late February sowing, and a 'Grasslánds Roa' tall fescue pasture was grazed twice.

'Grasslands Maru', phalaris established very well, and was faster than 'Grasslands Wana' cocksfoot, and some tall fescue stands.

\section{Grazing records}

Farmers are keeping grazing records for all paddocks sown, and for control paddocks. The results to date have little meaning, as half the pastures are less than 12 months old, but will be valuable from year two onwards.

However, one of the records taken near Ikawai (20 $\mathrm{km}$ south of Waimate) demonstrates that if dryland species are established correctly, it is possible to have no loss of production in the first year. From sowing on 3 March 1989 to 12 February 1990, one paddock of Roa tall fescue and Wana cocksfoot received 


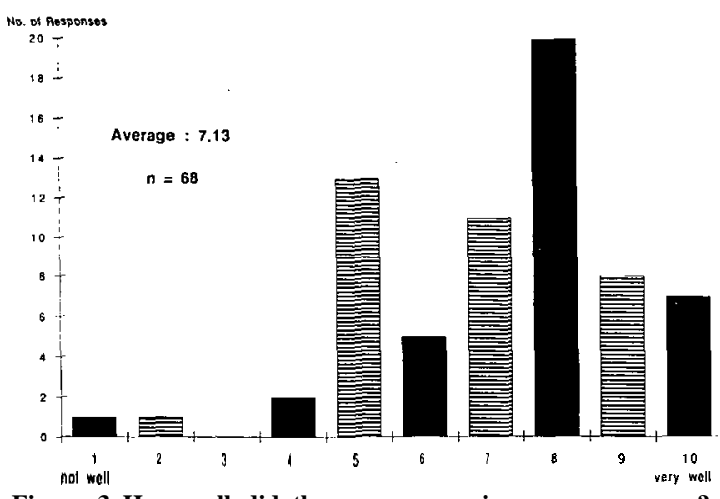

Figure 3 How well did the programme increase awareness?

10,410 stock unit grazing days per ha, equivalent to $25 \mathrm{su} / \mathrm{ha} / \mathrm{yr}$. Assuming $520 \mathrm{~kg} \mathrm{DM} / \mathrm{su}$ consumed and $80 \%$ pasture utilisation, this could equate to $520 \mathrm{~kg} / 0.8$ $\mathrm{x} 25 \mathrm{su}=16250 \mathrm{~kg} \mathrm{DM} /$ ha pasture growth, $140 \%$ above the district average for established ryegrass pastures.

\section{Survey}

To judge the effectiveness of the programme and also the opinions of dryland species, from a farmer perspective, a confidential questionaire was sent in May 1990 to all 81 farmers involved in the programme in May 1990; 70 responded.

Farmers rated their knowledge of drought species at 5.4 out of $10(1=$ poor, $10=$ very good $)$ before the programme, and 8.2 after, a $51 \%$ increase.

They felt that the programme had increased the awareness of drought species in their area, the average rating was 7.1 out of 10 (Figure 3). Farmers rated DSIR Grasslands assistance in the programme at 8.6 out of 10 .

A total of 801 farmers not included in the programme have visited and inspected these pastures. This is about $53 \%$ of the total number of farmers in the region (1500). Of the farmers outside the programme, 121 (13\% of region) have established drought pastures after gaining information from a farmer involved in the programme.

Respondents rated the success of establishment of the pastures on their farms at 7.4 out of 10 . This corresponds closely with the average scores of 6.9 given by pasture specialists as they inspected the North Otago and Waimate pastures. Only six of the 70 farmers who answered this question said the success was below average.

The rate of establishment, compared with that of ryegrass, was 4.3 out of 10 which indicates the drought pastures were slightly slower to establish $(5.0$ would indicate the same rate).

The production from the new pastures, compared with that of resident pastures, was felt to be 6.7 out of 10 (5.0 would indicate the same production). It is expected that the production from these pastures will not be much greater than that of resident pastures in the first 12 months but production advantages should be greater in the future.

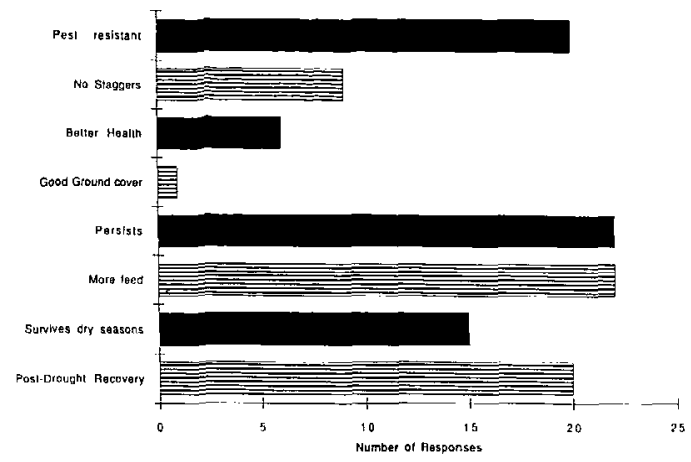

Figure 4 Advantages in sowing drought-tolerant pastures.

On average, $9.7 \%$ of farm areas were sown with some drought-tolerant species before the programme. After the programme, farmers thought $59 \%$ of their farm area would benefit from droughttolerant species.

When asked which species impressed them most, 29 said tall fescue, 22 cocksfoot, 11 phalaris, 11 prairie grass, 4 lucerne, 2 chicory, 1 each for soft brome, red and white clover, and 4 said it was too early.

Advantages listed of using drought-tolerant species were 115 in total. The main ones were high production (22), persistence (22), recovery after drought (20), pest tolerance or resistance (20). better survival of dry seasons (15), gave no ryegrass staggers (9), and better animal health (6) (Figure 4).

The disadvantages of drought species on their own farms were cited as: too slow to establish (24), establishment is more expensive (13), problems with palatability (8), require complicated grazing management (5), result in poor establishment (3); and 14 said they had no disadvantages at all (Fig. 5). Total disadvantages listed were 53 .

Farmers considered that the drought pastures designed were well suited to their farm, with an average score of 8.4 out of 10 . Of the farmers surveyed, $97 \%$ thought drought-tolerant pastures were economic on their farm, $3 \%$ thought that it was too early to tell, and none said they were uneconomic.

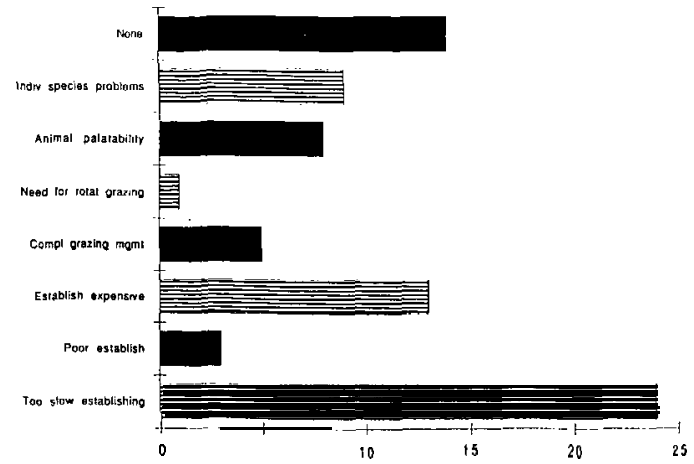

Figure 5 Disadvantages in sowing drought-tolerant pastures. 
This survey has therefore shown that even at this early stage in the programme, it has largely been successful. The programme has greatly increased the knowledge and confidence of these farmers in new drought-tolerant species. Most are convinced of the benefits and economic gains to be made from these species and this is quickly being passed on to their peers.

\section{Observations}

The most important factor in obtaining fast and successful establishment has been paddock preparation. Those paddocks cultivated and fallowed through summer had good levels of soil moisture that enabled sowing in February, despite very dry autumns. Fallowing has two effects: it reduces evapotranspiration and allows control of weed seed strikes. The combination of a seedbed which is weed free, moist and warm, results in rapid establishment of dryland species. Fallowing is just as important when direct drilling.

The most successful sowing time was 15-29 February; however, in this region soil conditions are almost always too dry for sowing at this time unless paddocks are fallowed. Paddocks sown before autumn rain periods fared better than those sown just after, probably because moisture is lost during the final cultivation. It is, however, impossible to sow one day before substantial rain. The only aspect farmers can control is preparation to allow for reasonable moisture before sowing.

Depth of sowing was also very important. Although farmers were told of the need to sow at shallow depths $(15 \mathrm{~mm})$, some were unable to achieve this. The results were lower field emergence and slower seedling growth.

-Cultivation seemed-to-encourage fäthēen, stinging nettle and chickweed. All spring 1989 sowings in North Otago had severe fathen problems (up to 200 plants $/ \mathrm{m}^{*}$ and 1.5 metres tall). This was best controlled with early MCPB applications and/or topping at $15 \mathrm{~cm}$. Most pastures survived the severe weed competition but plant numbers often declined by $20-50 \%$.

Phalaris tended to dominate in the first year when sown in the spring before a very dry summer, especially on sunny faces. Where phalaris mixtures are sown in the spring, phalaris rates should be below $2 \mathrm{~kg} / \mathrm{ha}$.

Patience is an important virtue when establishing dryland pastures in harsh environments. When stress occurs on these new pastures from lack of moisture, cool soils, low fertility, high weed populations or deep sowing, the rate of establishment is severely reduced. Many of the pastures were very sparse and weedy in the first 6 months compared with ryegrass, but within 12 months the improvement was quite spectacular. Farmer impatience was due to the expectation that establishment would be the same as for ryegrass. With experience, they realise that the appearance of a pasture in the first 6 months is irrelevant if it persists for more than 20 years.

It is not recommended that crops of ryecorn, Italian ryegrass or oats are used as greenfeed crops before sowing new pasture, especially if they are allowed to seed. The regrowth from seed sometimes caused serious competition through the winter and spring.

\section{Conclusions}

Demonstrating new species directly to a large number of farmers in a region is a most effective new approach to technology transfer. The first phase of this programme has been successfully implemented and has demonstrated to farmers that with the correct technical advice, the difficulty in establishing dryland pastures is low.

The success had led to two further programmes: an Otago Regional Council Direct Drilling Demonstration in autumn 1990, and the DSIR Grasslands East Coast North Island Pasture Demonstration of 1990-92.

The aspects most important for pasture establishment were paddock preparation, moisture at sowing, timing, sowing depth, insect control, soil fertility, initial grazing and patience.

Already, the programme has directly increased the knowledge that $\mathbf{8 8 2}$ farmers have of dryland species and the awareness among other farmers in the region. The next phase will aim to communicate the establishment methods and benefits of these pastures to as many farmers as possible.

North Otago and South Canterbury now have a foundation on which increased use of dryland species will be built for many years to follow, leading to a region with farmland more able to withstand the effects of future droughts, and that is more productive.

\section{ACKNOWLEDGEMENTS}

Richard McNamara and Jim Paton, MAFTech Oamaru, for rainfall, ET, and pasture data; Phil Tither, MAFTech Oamaru, for farm monitoring data; Edwina Melville for administrative support, survey assistance and paper preparation; farmers in the programme and those respondents to the survey; and Dr Phil Rolston for purchase of materials for the programme.

\section{REFERENCES}

Anon. 1979. Farm Monitoring Report - Farm Class 7A Review of 198849. June 1989.

Belgrave, B.R.; Watt, PC.; Brock, J.L. Wewala, S. Sedcole, J.R. 1990. A survey of farmer knowledge and use of pasture cultivars in New Zealand. NZ journal of agricultural research 33: 199-211. 